\title{
"Why Industrial Textile to Right Choice for Investment" (Analisis Laporan Keuangan PT. Eratex Djaja dan PT. Polychem Indonesia Tahun 2013-2017)
}

\author{
Fitrisia $^{1}$, Irma Suryani Indra ${ }^{2}$, Silmi $^{3}$ \\ ${ }^{1,2,3}$ Fakultas Ekonomi Pascasarjana Akuntansi Universitas Andalas, Padang, Indonesia \\ Correspondence email: Fitrisia25@gmail.com
}

\begin{abstract}
Abstrak. Investor membutuhkan bantuan analis untuk melakukan penilaian dan rekomendasi terkait dengan modal yang akan ditanamkan pada industry seperti apa dan keuntungan yang akan didapat seperti apa. Maka dari itu, analisis industry dapat membantu investor dalam menentukan pilihan. Salah satu pilihan industry yang bagus untuk melakukan investasi adalah di industry textile, karena kebutuhan barang textile merupakan kebutuhan pokok setiap orang untuk membuat pakaian dan barangbarang lain seperti boneka, selimut, tas dan dompet. Hal ini yang membuat industry textile perlu menjadi pertimbangan untuk melakukan investasi. Perkembangan industry textile di Indonesia mengalami banyak perubahan yang sangat pesat, karena saat sekarang ini sudah ada 43 perusahaan yang bergerak dibidang textile yang sudah go-public. Ini menunjukkan bahwa industry textile sangat bagus untuk dilakukan analisis investasi. Analisis menggunakan data keuangan industry selama lima tahun, dari tahun 2013 sampai dengan tahun 2017.
\end{abstract}

Kata kunci: Analisis Laporan Keuangan; Industry Textile; Investasi.

Abstract. Investors need analytical assistance to invest and related to what capital will be invested in the industry and what benefits will be obtained. Therefore, industry analysis can help investors make choices. One good industry choice for investing is the textile industry, because the needs of textile goods are everyone's basic needs for making clothes and other items such as dolls, blankets, bags and wallets. This makes the textile industry needs to be a consideration for investing. The development of the textile industry in Indonesia is growing rapidly, because there are currently 43 companies engaged in the textile sector that have gone public. This shows that the textile industry is very good for investment analysis. The analysis uses industry financial data for five years, from 2013 to 2017.

Keywords: Financial Statement Analysis; Textile Industry; Investation.

\section{PENDAHULUAN}

Industry di Indonesia saat ini banyak mengalami perubahan mulai dari yang disebabkan oleh krisis keuangan yang membuat daya beli masyarakat berkurang. Banyak factor yang membuat industry di Indonesia mengalami perubahan. Karna factor tersebut membuat investor berhati-hati untuk melakukan investasi. Jadi analis diperlukan untuk melakukan analisis pada laporan keuangan industry untuk memperoleh perusahaan dan industry mana yang bagus untuk berinvestasi. Penilaian dalam analisis keuangan bisa menggunakan berbagai metode analisis. Yang paling utama ada laporan keuangan Industry mana yang akan dilakukan analisis. Penilaian analisis sangat dibutuhkan untuk membuat rekomendasi yang bagus untuk membantu investor dalam memilih mereka menanamkan modalnya.

Penilaian dalam analisis laporan keuangan adalah dengan menganalisis laporan keuangan perusahaan dari tahun ke tahun untuk memperoleh hasil dan prediksi untuk tahun kedepannya. Analisis tidak hanya dibutuhkan oleh investor tapi juga para kreditor dan manajemen untuk menilai seberapa bagus kinerja perusahaan. Banyak perusahaan industry yang dapat dilakukan analisis dalam menentukan tempat yang baik untuk investasi. Penilaian dalam melakukan analisis yang paling utama adalah dilihat dari tingkat perputaran bisnis. Saat sekarang ini di Indonesia bisnis yang lagi banyak dilakukan orang adalah bisnis dibidang fashion, terutama bisnis pakaian. Karena pakaian diperlukan semua orang dan perputaran penjualan pakaian sangat bagus. Banyaknya anak muda sekarang yang mampu menciptakan model-model pakaian yang sangat diminati oleh kaum milineal atau anak muda saat sekarang ini. Jadi bisa kita simpulkan bahwa industry penghasil bahan untuk pakaian sangat dibutuhkan. Maka dari itu analisis dilakukan pada industry textile di Indonesia.

Laporan keuangan pasti dimiliki setiap perusahaan yang sudah go-public. Laporan keuangan dibuat untuk menjelaskan bagaimana kinerja perusahaan. Yang memerlukan laporan keuangan adalah pada investor, kreditor, manajemen, dan karyawan. Menurut Munawir (2010) laporan keuangan terdiri dari Neraca, Laba Rugi, dan Perubahan Ekuitas. Pendapat Munawir sudah tidak bisa dipakai lagi. Karena saat sekarang ini jenis laporan keuangan ada enam menurut PSAK 1 dari IAI (2014), laporan keuangan terdiri atas enam laporan, yaitu bebagai berikut:

1. Laporan posisi keuangan komparatif pada akhir periode 
Fitrisia et al, "Why Industrial Textile to Right Choice for Investment" (Analisis Laporan Keuangan PT. Eratex Djaja dan PT. Polychem Indonesia Tahun 2013-2017)

2. Laporan arus kas

3. Laporan laba rugi

4. Laporan perubahan ekuitas

5. Catatan atas laporan keuangan

6. Laporan posisi keuangan pada awal periode

Dari kelima jenis laporan keuangan diatas, analis akan menggunakan semuanya untuk melakukan analisis terhadap industry perusahaan. Mulai dari analisis laporan keuangan dengan menggunakan analisis rasio dan masih ada lagi analisis yang digunakan. Mereka memiliki tujuan sendiri terkait dengan laporan keuangan yang dikeluarkan oleh perusahaan. Jadi yang akan dibahas adalah bagaimana analisis laporan keuangan untuk menerik investor dalam berinvestasi. Menurut kasmir (2012), laporan keuangan adalah menunjukkan bagaimana keuangan perusahaan pada saat sekarang atau saat periode tertentu.

Menurut Fahmi (2009) aktivitas investasi secara umum terbagi menjadi dua bentuk yaitu:

1. Real Investment (Investor yang sesungguhnya)

Disini jelas bahwa investor melakukan investasi secara nyata yaitu dengan investasi terhadap asset berwujud, seperti mesin, pabrik, bangunan atau tanah.

2. Financial Investment (Investor yang berinvestasi secara keuangan)

Investor disini melakukan investasi keuangan untuk membeli seperti saham dan obligasi, yang secara umum dengan kontrak tertulis serta memperoleh keuntungan dalam jangka waktu pendek atau panjang.

Menurut Sofyan Syafri (2011) analisis adalah melakukan pememecahan atau penguraian sesuatu unit dan menjadikan unit-unit tersebut menjadi lebih kecil lagi. Analisis rasio sudah ada dijelaskan dalam annual report industry, tapi disini anlisis perlu melakukan analisis lagi dengan analisis rasio untuk memperoleh gambaran dari tahun-tahun yang diteliti agar bisa melakukan prediksi kedepan dari industry yang dianalisis. Menurut subramanyam (2017) ada beberapa analisis yang dapat digunakan oleh analis yaitu sebagai berikut ini:

1. Analisis Rasio

2. Analisis Cash Flow

3. Analisis Du-pont

4. Analisis Financial Leverage

5. Analisis EVA

6. Analisis Prospektif

7. Analisis Financial Distress

8. Analisis Commen Size

9. Analisis Equity Sekurities

10. Analisis Corporate Financing Policies

11. Analisis Investing Activity

Analisis diatas akan digunakan untuk memperoleh hasil yang lebih akurat untuk memberikan rekomendasi kedapa investor, serta dapat juga untuk meberikan rekomendasi untuk manajemen terkait dengan kinerja perusahaan. Pekerjaan analis menjadi lebih mudah jika menggunakan keseluruhan analisis karena semua jenis laporan keuangan dipakai dengan sebelas analisis diatas. Analisis digunakan untuk memperoleh prosepk kedepannya dari industry dan terkait dengan keputusan investor, manajemen dan kreditor terhadap kinerja insudtry terkait.

Investasi tidak hanya terjadi karena individu kelebihan modal, tapi bisa juga perusahaan melakukan investasi terhadap perusahaan lain. Disini dapat disimpulkan bahwa investor disini bisa individu atau perusahaan yang kelebihan dana untuk investasi pada industry yang akan direkomendasikan oleh analis. Analis juga bisa melakukan pengungkapan terkait analisis yang dilakukan untuk memperoleh analisis yang relevan terkait dengan keputusan yang akan direkomendasikan. Analisis digunakan untuk mengetahui keadaan yang sebenarnya dari laporan keuangan industry dengan berbagai alat analisis yang digunakan untuk menghasilkan rekomendasi yang tepat kepada investor dalam membantu pengambilan keputusan.

Analisis juga bisa dilakukan dengan terlebih dahulu melihat lingkungan bisnis industry kemudian mengevaluasi agar mendapatkan strategi yang dipakai industry terkait dengan bisnis yang dilakukan. Analisis juga harus mengetahui aktivitas bisnis industry, sejarah dan perkembangan industry untuk memperoleh pengetahuan yang harus dianalisis terkait dengan industry, seperti industry textile maka perlu dilakukan pengecekan terhadap persediaan dan penjualannya apakah bagus atau tidak.

Investasi yang dilakukan investor untuk memperoleh penghasilan yang tetap karena investasi dalam pasar modal deviden yang akan didapat investor akan dibagikan akhir tahun. Sedangkan bagi industry yang dijadikan tempat investasi akan menguntungkan untuk memperbesar industry dengan tambahan modal yang didapat dari investor. Jaminan bisnis dalam pasar modal lebih aman dari pada investasi dalam bentuk investasi dollar, dan jika melakukan investasi pada supplier maka bisnis akan selalau berjalan dengan baik karena pasar pasti membutuhkan supplier untuk bahan baku produk yang akan dihasilkan. Investasi dalam industry juga akan mengurangi persaingan karena investasi bisa mengurangi persaingan perusahaan yang memiliki industry yang sama.

\section{METODE \\ Populasi dan Sampel}

Populasi yang digunakan dalam penelitian ini adalah seluruh industry textile di Indonesia yang telah go-publik sebanyak 43 industry. Memperoleh 2 sampel perusahaan yaitu PT. Roda Vivatex dan PT. Polychem Indonesia. Dipilih berdasarkan kelengkapan annual report setiap tahun analisis dan kelengkapan data untuk setiap pengukuran analisis. 
Fitrisia et al, "Why Industrial Textile to Right Choice for Investment" (Analisis Laporan Keuangan PT. Eratex Djaja dan PT. Polychem Indonesia Tahun 2013-2017)

\section{Data yang Digunakan}

Data yang digunakan adalah data sekunder, data yang diperoleh dari pihak ketiga atau data yang sudah dioleh terlebih dahulu. Data penelitian diambil di bursa efek Indonesia, menggunakan data industry selama lima tahun mulai dari tahun 2013 sampai dengan tahun 2017. Data yang diambil yaitu annual report industry yang dianalisis.

Alat analisis yang digunakan

Alat analisis yang menjadi ukuran dalam memberikan rekomendasi terbaik dari analisis yang dilakukan adalah sebagai berikut:

1. Analisis Rasio

2. Analisis Cash Flow

3. Analisis Du-pont

4. Analisis Financial Leverage

5. Analisis EVA

6. Analisis Prospektif

7. Analisis Financial Distress

8. Analisis Equity Sekurities

9. Analisis Corporate Financing Policies

10.Analisis Investing Activity

Analisis dilakukan di Microsoft Excel untuk memudahkan analis dalam melakukan perhitungan rumus dari setiap analisis diatas, serta memudahkan dalam melihat grafik trend dari setiap industry dan analisis yang dilakukan. Metode yang digunakan untuk memudahkan analisis yang dilakukan analis dalam mengambil kesimpulan rekomendasi untuk investor. Serta jaminan atas bukti dari analisis akan memberikan investor gambaran kondisi industry dan pilihan yang tepat mendukung keputusan investor. Tidak mudah melakukan analisis dengan alat yang banyak karena akan mempersulit dalam analisis dan memberikan waktu yang panjang untuk analis melakukan analisis dengan benar dan akurat karena terkait dengan pilihan investor dalam investasi.

\section{Pengukuran Analisis}

Analisis Rasio

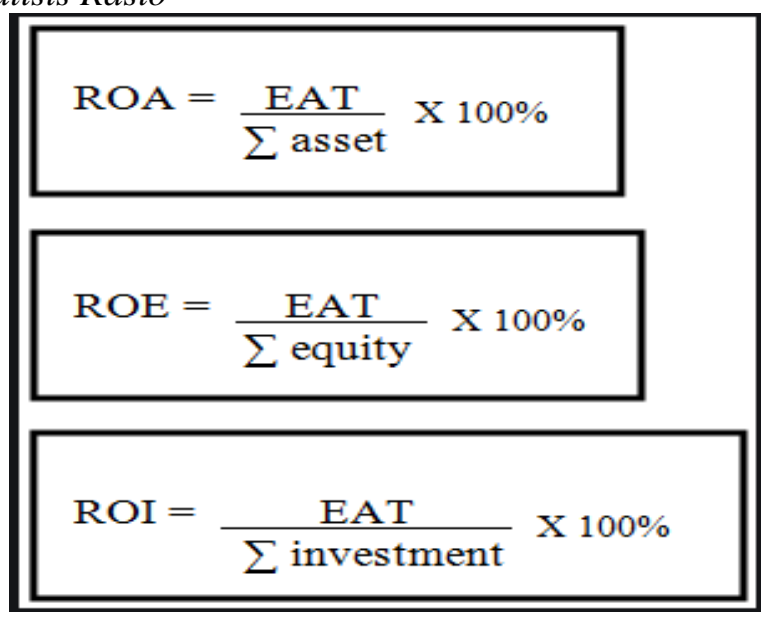

Analisis Du-pont dan Financial Levergare

\begin{tabular}{|c|c|c|c|c|}
\hline$\times$ & \multicolumn{4}{|c|}{ DuPontFormula (Return on Equiy) } \\
\hline \multicolumn{3}{|c|}{ Return on Asset (ROA) } & \multirow[t]{2}{*}{$x$} & Leverage \\
\hline Profitability & $x$ & Operational Efficiency & & Financial Leverage \\
\hline Net Income & \multirow{2}{*}{$x$} & Sales & \multirow{2}{*}{$x$} & Assets \\
\hline Sales & & Assets & & Equity \\
\hline & & ROE $=$ Net Income & $E q$ & \\
\hline
\end{tabular}

$$
\mathrm{DFL}=\frac{\text { persentase perubahan EPS }}{\text { persentase perubahan EBIT }}
$$

Analisis EVA dan Analisis Prospektif

- $\mathrm{EVA}=$ Modal yang digunakan $(\mathrm{ROI}-$ Biaya modal $)$

Rata-rata piutang $=\frac{\text { Piutang awal + piutang akhir }}{2}$

Perputaran piutang=

Penjualan / Pendapatan

Rata-rata piutang

Analisis Financial Distress

$Z \quad 3.3 \frac{\text { EBIT }}{\text { Total Assets }}+1.2 \frac{\text { Net Working Capital }}{\text { Total Assets }}+1.0 \frac{\text { Sales }}{\text { Total Assets }}$ $+0.6 \frac{\text { Market Value Equity }}{\text { Book Value Equity }}+1.4 \frac{\text { Accumulated Retain Earnings }}{\text { Total Assets }}$

Analisis Equity Sekurities dan Analisis Cash Flow

$\mathrm{R}_{\mathrm{i}}=\mathrm{R}_{\mathrm{f}}+\beta_{\mathrm{i}}\left(\mathrm{R}_{\mathrm{m}}-\mathrm{R}_{\mathrm{f}}\right)$

di mana:

$\mathrm{R}_{\mathrm{i}}=$ Tingkat keuntungan yang disyaratkan oleh sekuritas i

$R_{\mathrm{f}}=$ Tingkat keuntungan bebas risiko

$\mathrm{R}_{\mathrm{m}}=$ Tingkat keuntungan yang disyaratkan rata-rata dengan beta $=1$ atau tingkat keuntungan pasar

$\beta_{\mathrm{i}} \quad=$ Koefisien beta sekuritas $\mathrm{i}$

\section{Cash Flow = EBIT $(1-\mathrm{T})+$ Depresiasi}

Dimana :

EBIT = Laba Sebelum Bunga dan pajak

$\mathrm{T} \quad=$ Pajak penghasilan perusahaan

Depr $=$ Beban Penyusutan

Analisis Investing

Investing Policy Ratio $=\frac{\text { Securities }}{\text { Total Deposit }} 100 \%$


Fitrisia et al, "Why Industrial Textile to Right Choice for Investment" (Analisis Laporan Keuangan PT. Eratex Djaja dan PT. Polychem Indonesia Tahun 2013-2017)

\section{HASIL DAN PEMBAHASAN}

Analisis akan memberikan gambaran terkait dengan alat analisis yang digunakan analis dalam melakukan analisis. Diatas telah dijelaskan bahwa alat yang digunakan dalan analisis pada industry textile ada sebelas untuk memperoleh rekomendasi yang tepat. Analisis digunakan untuk memperoleh nilai yang merupakan bukti untuk memberikan rekomendasi terkait dengan analisis industry yang dilakukan oleh analis.

Analisis rasio digunakan untuk melihat aktivitas industry dalam baik untuk jangka pendek dan jangka panjang, karena rasio yang digunakan adalah rasio likuiditas dan rasio profitabilitas. Rasio likuiditas menjelaskan bagaimana kemampuan perusahaan untuk membayar kewajiban financial jangka pendek. Sedangkan pada rasio profitabilitas menjelaskan bagaimana kemampuan perusahaan mendapatkan laba melalui sumber dana yang dipunyai perusahaan. Tidak hanya analisis rasio analisis lainnya juga akan tergambar ditabel diawah ini terkait dengan hasil anlisis yang sudah digunakan dalam penelitian ini.

Jadi dari analisis dapat digambarkan bahwa kedua industry yang analisis dapat digambarkan hasilnya dengan rincian dari tahun serta metode yang dapat digunakan dalam analisis rasio yang digunakan yaitu rasio likuiditas dan rasio profitabilitas, sebagai berikut ini:

\section{Analisis Rasio}

Tabel 1. Analisis Rasio

\begin{tabular}{|c|c|c|c|c|c|c|}
\hline \multicolumn{7}{|l|}{ Rasio Likuiditas } \\
\hline & 2013 & 2014 & 2015 & 2016 & 2017 & \\
\hline Polychem Indonesia & 2.635 & 2.55 & 2.555 & 1.858 & 2.152 & \multirow{2}{*}{ Current Ratio } \\
\hline Roda Vivatex & 0.241 & 0.903 & 2.061 & 3.253 & 4.617 & \\
\hline & 2013 & 2014 & 2015 & 2016 & 2017 & \\
\hline Polychem Indonesia & 1.436 & 1.39 & 1.518 & 1.047 & 1.261 & \multirow{2}{*}{ Quick Ratio } \\
\hline Roda Vivatex & 0.202 & 0.893 & 2.059 & 3.246 & 4.606 & \\
\hline & 2013 & 2014 & 2015 & 2016 & 2017 & \\
\hline Polychem Indonesia & 0.262 & 0.422 & 0.523 & 0.282 & 0.394 & Cash Ratio \\
\hline Roda Vivatex & 0.022 & 0.417 & 1.568 & 2.633 & 4.156 & \\
\hline
\end{tabular}

\begin{tabular}{|c|c|c|c|c|c|c|}
\hline \multicolumn{7}{|l|}{ Rasio Profitabilitas } \\
\hline & 2013 & 2014 & 2015 & 2016 & 2017 & \\
\hline Polychem Indonesia & 0.029 & -0.035 & -0.048 & -0.073 & 0.016 & Gross Profit Margin \\
\hline Roda Vivatex & 1.668 & 1.548 & 1.357 & 1.348 & 1.43 & \\
\hline & & & & & & \\
\hline & 2013 & 2014 & 2015 & 2016 & $201 /$ & \\
\hline Polychem Indonesia & -0.005 & 0.0004 & 0.0004 & -0.0062 & 0.0078 & Net Profit Margin \\
\hline Roda Vivatex & 0.554 & 0.609 & 0.606 & 0.633 & 0.629 & \\
\hline & 13 & 2014 & 2015 & 2016 & 2017 & \\
\hline Polychem Indonesia & 0.009 & -0.114 & $\begin{array}{r}2010 \\
-0.111 \\
\end{array}$ & $\begin{array}{r}2010 \\
-0.095\end{array}$ & -0.039 & ROE \\
\hline Roda Vivatex & 0.173 & 0.173 & 0.163 & 0.142 & 0.12 & \\
\hline
\end{tabular}

*) sumber data diolah dengan Microsoft Excel

Rasio Likuiditas yang dihasilkan kedua industry, mencerminkan bagaimana industry mampu memenuhi kewajiban jangka pendek terkait dengan data yang digunakan selama lima tahun. Sedangkan analisis pada profitabilitas menjelaskan bagaimana kemampuan perusahaan memperoleh laba selama periode 2013 sampai 2017. Dari analisis sudah diketahui bahwa PT.
Roda Vivatex lebih bagus industry dalam mengelola kewajiban jangka pendek dan perolehan laba yang bagus, berbeda dengan PT. Polychem Indonesia yang mengalami kerugian di laporan rasio profitabilitasnya dan tercermin dari laporan laba rugi industry.

\section{Analisis Du-pont dan Analisis Financial Leverage}

Tabel 2. Analisis Du-pont dan Financial Leverage ANALISIS FINANCIAL LEVERAGE

PT. RODA VIVATEX

\begin{tabular}{|l|r|r|r|r|r|}
\hline & 2013 & 2014 & 2015 & 2016 & 2017 \\
\hline EBIT & $2.3217 \mathrm{E}+11$ & $2.5847 \mathrm{E}+11$ & $2.4849 \mathrm{E}+11$ & $2.311 \mathrm{E}+11$ & $2.4914 \mathrm{E}+11$ \\
\hline EBT & $2.3171 \mathrm{E}+11$ & $2.6281 \mathrm{E}+11$ & $2.5603 \mathrm{E}+11$ & $2.5726 \mathrm{E}+11$ & $2.4914 \mathrm{E}+11$ \\
\hline DFL & $100 \%$ & $98 \%$ & $97 \%$ & $90 \%$ & $100 \%$ \\
\hline
\end{tabular}

PT. POLYCHEM INDONESIA

\begin{tabular}{|l|r|r|r|r|r|}
\hline & 2013 & 2014 & 2015 & 2016 & 2017 \\
\hline EBIT & 14689673 & 15799211 & 14985679 & 20491886 & 6002890 \\
\hline EBT & 14718207 & 33644523 & 28922199 & 28114407 & 11751064 \\
\hline DFL & $100 \%$ & $47 \%$ & $52 \%$ & $73 \%$ & $51 \%$ \\
\hline
\end{tabular}

Analisis Du-pont

ROE

\begin{tabular}{l|r|r|r|r|r|}
\hline & 2013 & 2014 & 2015 & 2016 & 2017 \\
\hline Polychem Indonesia & 0.0062 & -0.085 & -0.0902 & -0.0837 & -0.036 \\
\hline Roda Vivatex & 0.173 & 0.173 & 0.164 & 0.142 & 0.121 \\
\hline
\end{tabular}

*) sumber data diolah dengan Microsoft Excel

Analisis du-pont yang dihasilkan industry PT. Roda Vivatex lebih bagus dibandingkan PT. Polychem Indonesia yang tidak bisa memperoleh nilai yang meningkat malah minum untuk trend berikutnya. Sedangkan untuk financial leverage sangat jelas industry PT. Roda Vivatex lebih bagus dibandingkan PT.Polychem Indonesia yang fluktuatif turun dan meningkat dengan dratis.

\section{Analisis EVA dan Analisis Prospektif}

Tabel 3. Analisis EVA dan Prospektif

Anlisis EVA

\begin{tabular}{|l|r|r|r|r|r|}
\hline & 2013 & 2014 & 2015 & 2016 & 2017 \\
\hline Polychem Indonesia & 19779000.8 & -24707194.5 & -24161213.5 & -20569760.6 & -8647864.83 \\
\hline Roda Vivatex & $1.2928 \mathrm{E}+10$ & 21611502012 & 26344342160 & 28821651089 & 43059201759 \\
\hline
\end{tabular}

ANALISIS PROSPEKTIF ANALISIS

PROYEKSI PUITANG USAHA

\begin{tabular}{l|r|r|r|r|r|}
\hline & 2013 & 2014 & 2015 & 2016 & 2017 \\
\hline PT. POLYCHEM INDONESIA & 51296293 & 40188429 & 39285770 & 39091151 & 41271874 \\
\hline PT. RODA VIVATEX & $4.2085 \mathrm{E}+10$ & $7.0093 \mathrm{E}+10$ & $5.3823 \mathrm{E}+10$ & $4.8661 \mathrm{E}+10$ & $9.814 \mathrm{E}+09$ \\
\hline
\end{tabular}

*) sumber data diolah dengan Microsoft Excel 
Analisis EVA kedua industry sangat bagus dengan hasil EVA lebih besar dari nol (0) menandakan perusahaan memperoleh nilai tambah yang bagus dan kinerja yang bagus dari hasil analisi yang dilakukan oleh analis. Ini sangat baik untuk kedua industry textile yang dianalisis karena tidak terjadi penurunan kinerja perusahaan.

\section{Analisis Financial Distress}

Tabel 4. Analisis Financial Distress

Analisis Financial Distress

\begin{tabular}{|l|r|r|r|r|r|}
\hline & 2013 & 2014 & 2015 & 2016 & 2017 \\
\hline Polychem Indonesia & -1.840 & -1.926 & -1.985 & -2.038 & -2.155 \\
\hline Roda Vivatex & -3.396 & -3.929 & -4.07 & -4.129 & -4.242 \\
\hline
\end{tabular}

*) sumber data diolah dengan Microsoft Excel

Analis menggunakan $\mathrm{X}$-sroce dalam melakukan analisis financial distress, hasil yang diperoleh sangat bagus terkait dengan industry yang dianalisis yaitu kedua industry yang dianalisis mengalami keadaan sehat untuk laporan keuangan selama lima tahun analisis. Ini sangat bagus untuk kedepannya, karena tercermin bagaimana kesehatan industry dan bisa diprediksi untuk kedepannya akan sehat juga. Berarti industry dalam kondisi yang bagus untuk diberikan investasi oleh investor dan diberikan pinjaman oleh kreditor. Terkait dengan pengembangan perusahaan untuk kedepannya. Kondisi yang bagus atau sehat belum tentu bisa secara keseluruhan menggambarkan kondisi industry dan kinerja perusahaan. Ini hanya salah satu analisis yang bisa digunakan analis membantu menyakinkan investor.

\section{Analisis Equity Sekurities dan Analisis Cash Flow}

Tabel 5. Analisis Equity Sekurities dan Cash Flow ANALISIS EQUITY SEKURITIES

Analisis fundamental

\section{HARGA SAHAM}

\begin{tabular}{|l|r|r|r|r|r|}
\hline & 2013 & 2014 & 2015 & 2016 & 2017 \\
\hline PT.POLYCHEM INDONESIA & 189 & 152 & 72 & 126 & 246 \\
\hline PT.RODA VIVATEX & 738 & 869 & 966 & 971 & 922 \\
\hline
\end{tabular}

\section{ANALISIS CASH FLOW}

FCF (Arus kas Bebas)

\begin{tabular}{l|r|r|r|r|r|}
\hline & 2013 & 2014 & 2015 & 2016 & 2017 \\
\hline Polychem Indonesia & -558758332.000 & -490773750.000 & -444171446.000 & -401444283.000 & -382758168.000 \\
\hline Roda Vivatex & $-1.35145 E+12$ & $-1.41075 E+12$ & $-1.6135 E+12$ & $-1.841744+12$ & $-2.03355 E+12$ \\
\hline
\end{tabular}

*) sumber data diolah dengan Microsoft Excel

Dari analisis sangat jelas bagaimana kondisi industry dengan hanya melihat angka dan harga saham, dimana industry PT. Roda Vivatex lebih bagus dalam analisis equity sekurities yang mencerminkan bagaimana harga saham lebih tinggi dan nilainya lebih stabil dibandingkan industry PT. Polychem Indonesia. Sedangkan dalam analisis cash flow kedua industry tidak bisa memanfaatkan arus kas bebasnya sehingga nilai analisis yang didapat adalah negative untuk kedua industry selama periode analisis. Ini tidak baik untuk kedua industry kerena tidak bisa memanfaatkan apa yang sudah ada dalam perusahaan.

\section{Analisis Investing}

\begin{tabular}{|c|c|c|c|c|c|}
\hline \multicolumn{6}{|c|}{ Tabel 6. Analisis Investing } \\
\hline \multicolumn{6}{|c|}{ INVESTING ACTIVITY ANALYSIS } \\
\hline \multicolumn{6}{|l|}{ RETURN ON INVESTASI } \\
\hline & 2013 & 2014 & 2015 & 2016 & 2017 \\
\hline PT.POLYCHEM INDONESIA & $0 \%$ & $-5 \%$ & $-6 \%$ & $-5 \%$ & $-2 \%$ \\
\hline PT. RODA VIVATEX & $13 \%$ & $14 \%$ & $14 \%$ & $12 \%$ & $11 \%$ \\
\hline
\end{tabular}

*) sumber data diolah dengan Microsoft Excel

Analisis investing activity sangat jelas bahwa hasil analisis industry PT. Roda Vivatex lebih bagus dalam melakukan investing dibandingkan dengan industry PT. Polychem Indonesia yang ada masanya tren investing industry nol (0) ini tidak bagus untuk kinerja perusahaan untuk menarik investor dalam melakukan investasi.

Dari analisis yang digunakan dapat dijelaskan bahwa industry PT. Roda Vivatex lebih bagus dalam kinerja dan pemanfaatan seluruh asset dan investasi untuk meningkatkan kinerja industry terkait dengan analisis yang dilakukan. Secara garis besar analisis yang dilakukan analis sudah tergambar bahwa untuk investasi lebih baik memilih PT. Roda Vivatex dengan hasil analisis yang selalu lebih tinggi dibandingkan dengan PT. Polychem Indonesia yang terkadang bisa dibawah standar nilai analisis yang digunakan.

Investasi yang dilakukan investor dapat membantu industry dalam membeli asset terkait dengan industry yang dilakukan seperti membeli tanah untuk perluasan pabrik. Serta juga memenuhi kebutuhan industry ditahun depan sebagai pemberian dukungan terhadap kebutuhan yang harus dipenuhi industry mengelola produk yang dihasilkannya. Kehidupan saat sekarang ini banyak investor melakukan investasi untuk kebutuhan masa depannya serta menjadikannya tabungan jika berkaitan dengan investasi jangka panjang yang akan dilakukan investor. Investor dapat menanamkan saham, deposito, obligasi dan reksadana di industry PT. Roda Vivatex yang lebih baik kinerja dan kondisi industrynya dibandingkan dengan PT. Polychem Indonesia yang pernah mengalami kerugian tiga tahun berturut-turut.

\section{SIMPULAN}

Sangat jelas bahwa hasil dari penelitian pada industry textile, PT. Roda Vivatex lebih bagus kinerjanya dibandingkan PT. Polychem Indonesia. Dari keseluruhan analisis PT. Roda Vivatex lebih unggul dan 
Fitrisia et al, "Why Industrial Textile to Right Choice for Investment" (Analisis Laporan Keuangan PT. Eratex Djaja dan PT. Polychem Indonesia Tahun 2013-2017)

tidak ada yang dibawah PT. Polychem Indonesia analisisnya. Laba pada perusahaan PT. Polychem Indonesia sangat sedikit dan beban yang besar untuk penjualan barang tidak sesuai dengan yang seharusnya diharapkan investor. Beban yang tinggi membuat industry PT. Polychem Indonesia mengalami kerugian. Dapat disimpulkan dari analisis diatas bawah analisis dapat diberikan kepada:

1. Investor jangka pendek dapat memilih PT. Roda Vivatex untuk berinvestasi karena perputaran pembayaran kewajiban jangka pendek pada rasio likuiditas lebih baik dibandingkan industry PT. Polychem Indonesia. Dilihat dari ROI dan ROE bahwa industry PT. Roda Vivatex lebih bagus memanfaatkan investasi dan equitasnya jelas ini akan memberikan keuntungan bagi investor jangka pendek.

2. Investor jangka panjang dapat memilih PT. Roda Vivatex unutk berinvestasi karena keuntungan jangka panjang yang bagus terjadi di PT. Roda Vivatex tergambar dari rasio profitabilitas, analisis du-pont, analisis financial leverage, analisis equity sekuritas dan analisis investing activity. Sangat jelas bahwa keseluruhan analisis lebih bagus industry PT. Roda Vivatex untuk berinvestasi jangka panjang.

3. Untuk kreditor lebih memilih PT. Roda Vivatex untuk diberikan pinjaman karena mampu membayar kewajiban jangka pendek dan jangka panjang. Untuk PT. Polychem Indonesia kredit diberikan dengan jaminan tertentu dan jangka waktu tertentu. Kerugian pada PT. Polychem Indonesia akan memberikan kemudahan untuk kreditor dalam mempertimbangkan pemberiaan pinjaman atau memperpanjang waktu pinjaman.

4. Untuk manajemen industry PT. Roda Vivatex harus bisa mempertahankan kinerja perusahaan dan meningkatkan cash flow nya untuk lebih baik lagi. Sedangkan untuk manajemen PT. Polychem Indonesia sebaiknya melakukan evaluasi terhadap struktur organisasi dan kinerja setiap karyawan untuk memperoleh peningkatan kinerja dalam perusahaan. Beban yang harus diperkecil agar tidak terjadi kerugian di dalam laporan keuangan industry PT. Polychem Indonesia.

\section{DAFTAR PUSTAKA}

Abraham, V., and S.K. Sasikumar. (2011). Labor Cost and Export Behavior of Firms in Indian Textile and Clothing Industry. Economics, Management, and Financial Markets 6 (1): 258-282

Akhtaruzzama M., and Hasanuzzaman S. (2012). Exploring Prospect of the Clothing and Textile Industry: Is Bangladesh Following a Right Growth Strategy? World Journal of Social Sciences 2 (4): 150-161.

Arliani, T.W. (2009). Analisis Faktor-Faktor yang Mempengaruhi Investasi di Propinsi Daerah
Istimewa Yogyakarta. Jurnal Riset Daerah 8: 1060-1073

Biselli, M. (2009). China's Role in the Global Textile Industry. Student Research Projects/Outputs. China Europe International Business School. Shanghai, People's Republic of China.

Bhandari, A.K., and P. Maiti. (2007). Efficiency of Indian Manufacturing Firms: Textile Industry as a Case Study. International Journal of Business and Economics 6(1): 71-88.

Embassy of Denmark. (2010). Overview of the Textile and Garment Sector in Vietnam. Business to Business Programme.

Firdaus, M., R. Oktaviani, A. Asmara, dan Sahara. (2008). Analisis Struktur, Perilaku dan Kinerja Industri Manufaktur di Indonesia. Working Papers Series No. 04/A/III/2008. Institut Pertanian Bogor.

Fahmi, Irham., dan Yovi Lavianti Hadi, (2009), Teori Portofolio dan Analisis Investasi, Pustaka Utama: Jakarta.

Gera, N. (2012). Significance and Future Prospects of Textile Export in Indian Economy. International Research Journal 2(1): 2-17.

Harahap, Syofyan Syafri., (2011), Teori Akuntansi Edisi Revisi 2011, Rajawali Pers, Jakarta.

Hassan, Y., et al. (2012). The Comprehensive Study of the Capital Structure of Textile Composite in Pakistan Over The Decade. Interdisciplinary Journal of Contemporary Research in Business 3(9): 311-324

Ikatan Akuntansi Indonesia, (2014), Standar Akuntansi Keuangan, Salemba Empat: Jakarta

Islam, M. M., A. M. Khan, and M. M. Islam. (2013). Textile Industries in Bangladesh and Challenges of Growth. Research Journal of Engineering Sciences 2(2): 31-37.

Kasmir, (2012), Analisis Laporan Keuangan, PT. Raja Grafindo Persada : Jakarta.

Kouliavtsev M, S. Christoffersen, and P. Russel. (2007). Productivity, Scale and Efficiency In The U.S. Textile Industry. Empirical Economics32: 1-18.

Kurniati, Y., D.F. Anugrah, dan T. Chawwa. (2008). Peran Investasi dalam Mendorong Pertumbuhan Ekonomi.Working Paper Bank Indonesia WP/06/2008.Bank Indonesia.

Nugroho, S.B.M. (2008). Evaluasi Terhadap FaktorFaktor yang Mempengaruhi Investasi di Indonesia dan Implikasi Kebijakannya.Riptek 2: 18-21.

Oktaviani, R., M. Firdaus, A. Asmara, S.H.Pasaribu, dan Sahara. (2007). Analisis Kinerja, Keragaan Ekonomi dan Prospek Industri Manufaktur di Indonesia.Jakarta:Departemen Perindustrian.

Scellato, G. (2007). Petents, Firm Size and Financial Constraints: An Empirical Analisis for a Panel of Italian Manufacturing Firms.Cambridge Journal of Economics 31: 55-57. 
Fitrisia et al, "Why Industrial Textile to Right Choice for Investment” (Analisis Laporan Keuangan PT. Eratex Djaja dan PT. Polychem Indonesia Tahun 2013-2017)

Suryawati, (2009). Analisis Struktur, Perilaku dan Kinerja Industri Tekstil dan Pakaian Jadi di Provinsi DIY, Jurnal Akuntansi dan Manajemen 20(1), 35-46.

Subramanyam, K.R., dan Wild, John, J., (2017), Analisis Laporan Keuangan Edisi 11 Buku 1, Penerjemah: Febriela Sirait, Teguh Iman Maulana, Salemba Empat, Jakarta.

Subramanyam, K.R., dan Wild, John, J., (2017), Analisis Laporan Keuangan Edisi 11 Buku 2, Penerjemah: Febriela Sirait, Teguh Iman Maulana, Salemba Empat, Jakarta.

Munawir, S., (2010), Analisis Informasi Keuangan, Edisi 3, Liberty. Yogyakarta

Tahir, M, \& Anuar, M. B. A. (2016). The determinants of working capital management and firms performance of textile sector in pakistan. Quality and Quantity, 50(2), 605-618. https://doi.org/10.1007/s11135-015-016-4.

Tidajoh, B. E. (2015). Pengaruh contingent fit antara strategi kompetisi dan investment opportunity set terhadap kinerja perusahaan dengan corporate governance sebagai faktor moderasi. Disertasi.

Tjahjadi, B. (2011). Factors affecting the enterprise performance. Journal of Economic, Business and Accountancy Ventura, 14(110), 149-160.

Yusuf, A. (2002). Environmental uncertainly, the enterpreneeurial orientation of business ventures and performance. IJCM, 12(3), 83-103. 